\title{
LEGIONELINE PNEUMONIJA: IDENTIFIKAVIMAS IR INFORMACIJOS TEIKIMAS
}

\author{
Šarūnas Masys ${ }^{1}$, Edvardas Naujalis $^{1}$, Dominyka Kaušaité ${ }^{2}$ \\ ${ }^{1}$ Respublikinè Šiauliu ligoninè, ${ }^{2}$ Vilniaus universiteto Medicinos fakultetas
} Raktažodžiai: legioneliozè, legionierių liga, Legionella
pneumophila, pneumonija. diagnozę ir apie ją pranešti atitinkamoms institucijoms, kad būtų nustatytas ligos šaltinis ir galimas protrūkis.

\section{İvadas}

Pirmasis legioneliozès protrūkis ịvyko 1976 metais tarp Amerikos legiono suvažiavimo Filadelfijoje dalyvių, gyvenusių tame pačiame viešbutyje: susirgo 221, iš jų 34 mirè. Dèl to legioneliozè kartais vadinama legionierių liga. 1977 m. išskirtas sukèlèjas, G-bakterija Legionella pneumophila. Vèliau retrospektyviniais serologiniais tyrimais įrodyta, kad ta pati bakterija sukèlè ankstesnius pneumonijos protrūkius Jungtinèse Amerikos Valstijose (1965 m. Vašingtone, 1968 m. Pontiako mieste Mičigane) ir Ispanijos Benidormo kurorte (1973 m.) [1]. 1985 m. retrospektyviai diagnozuotas pirmasis legioneliozès atvejis Lietuvoje [2] Legionelioze vadinama liga, kurią gali sukelti bet kuri Legionella šeimos bakteriju rūšis. Legioneliozès yra dvi formos: legionelinè pneumonija ir Pontiako karštlige (lengvesne forma) [3]. Pneumonijos atveju būtina hospitalizacija, o Pontiako karštligè dažnai praeina savaime [4]. Žmogus legionelioze užsikrečia aerozoliniu būdu, įkvėpęs aerozolio su legionelèmis [5]. Dažniausiai legionelių randama oro kondicionieriuose, aušintuvuose, kompresorinėse, dušinėse, baseinuose, ịvairioje medicininėje aparatūroje [6]. L. pneumophila sukelia sunkią atipinę pneumoniją, todèl labai svarbu surinkti teisingą epidemiologinę anamnezę ir kiekvienos pneumonijos atveju pagalvoti apie ši sukèlèją, kadangi negydoma liga neretai gali baigtis mirtimi [5]. İtariant legionelinę pneumoniją, rekomenduojama atlikti vieną iš jautriausių ir specifiškiausių tyrimų - L. pneumophila antigeno nustatymą šlapime [7]. İtarus legionelinę pneumoniją, prieš paimant šlapimo èmini, galima pradèti empirinę antibiotikų terapiją fluorochinolonais ir makrolidais [8]. Svarbu apie ligą pranešti, o legionierių ligos profilaktikos esmè - Legionella bakterijų rezervuaro paieškos ir jo kenksmingumo pašalinimas terminiu ar cheminiu būdais [2].

Tyrimo tikslas - išanalizuoti legioneliozès etiologiją, epidemiologiją, diagnostiką, gydymą, profilaktiką bei pranešimo apie legioneliozę svarbą. 


\section{Tyrimo medžiaga ir metodai}

Literatūros apžvalga atlikta remiantis elektroninėmis $\mathrm{Pu}$ bMed ir Google Scholar mokslo duomenų bazėmis, atrenkant publikacijas anglų kalba nuo 2015 iki 2021 metų, naudojant raktažodžius originalo kalba: Legionellosis, Legionnaires“ disease, Legionella pneumophila; pneumonia.

\section{Tyrimo rezultatai}

Etiologija. Legionella - tai Gram (-) aerobinès bakterijos. Jos yra 0,3-0,9 mikronų pločio ir 2-20 mikronų ilgio lazdelès, augančios mitybinèse terpèse, turinčiose anglies, mielių ekstrakto, cisteino [2,9]. Legionella kolonijos aptinkamos 3-5 dienos po kultivacijos [10]. Legionella genti sudaro 58 genetiškai skirtingos rūšys ir 3 subrūšys [10]. Žmogui patogeniškos - 18 rūšių, 90 proc. infekcijos atvejų sukelia L. pneumophila, iš jų daugiau kaip 80 proc. - 1 serogrupès. Legionella bakterijų randama natūralioje ir žmogaus sukurtoje aplinkoje: upių, ežerų, vandentiekio vandenyje ir kt. Daugejjant kondicionavimo ịrangos, ịvairių vandens baseinų, sūkurinių vonių bei kitos vandens ịrangos buityje, didèja ir galimybès Legionella bakterijoms plisti [11].

Epidemiolgija. Legioneliozė priskiriama sapronozėms. Infekcijos rezervuaras yra vanduo, kuriame natūraliose sąlygose legionelès egzistuoja [3]. Natūraliuose vandens telkiniuose esti tik nedideli legionelių kiekiai. Žemesnèje nei $20{ }^{\circ} \mathrm{C}$ ir aukštesneje nei $60{ }^{\circ} \mathrm{C}$ temperatūroje legionelès nesidaugina, palankiausia $20-45^{\circ} \mathrm{C}$ temperatūra [12]. Legionelès paplitusios natūraliuose ir dirbtiniuose vandens telkiniuose (upėse, ežeruose) [10]. Legionelių neveikia ịprastinès chloro dozès, todèl jų nedideli kiekiai patenka ị vartojamojo vandens paskirstymo sistemą [12]. Legionelių randama oro kondicionieriuose, aušintuvuose, kompresorinèse, dušinèse, baseinuose, medicininèje aparatūroje, taikomoje respiracinei terapijai [13-15]. Žmogus dažniausiai užsikrečia ịkvẻpdamas aerozolio (smulkių lašelių), kuriame yra bakterijų [16]. Labai retai žmogus gali užsikrèsti, įtraukęs užkrèsto vandens. Legionelioze neužsikrečiama nuo sergančio žmogaus, geriant užkrèstą vandenị bei vartojant maisto produktus, kurių paruošimui naudotas užkrėstas vanduo [12].

Legioneliozès rizikos veiksniai $[6,17]$ :

- vidutinis ar senyvas amžius;

- rūkymas, alkoholio vartojimas;

- lètinès plaučių ligos, lètinè obstrukcinè plaučių liga (lopl) ir kt.

- imunodeficitinès būklès:

- ypač dẻl kortikosteroidų, imunosupresinių medikamentų;

- didžiausia rizika pacientams po organų persodinimo;

- piktybinès ligos;

- lètinis inkstų nepakankamumas;
- cukrinis diabetas;

- hospitalinès infekcijos - buvusi chirurginè intervencija.

Veiksniai, didinantys Legionella bakterijų buvimo aplinkoje tikimybę $[17,18]$ :

- neseniai buvusi kelionè, kruizinis laivas, nakvynè viešbutyje;

- hospitalizavimas;

- buvimas slaugos ligoninèje;

- namų šulinio vandens naudojimas;

- neseniai buvę santechnikos darbai namuose arba darbe;

- blogai prižiūrimi mineralinių vandenų kurortai.

Klinika. Yra 2 ligos formos: lengva ir sunki. Lengva Pontiako karštine, kuri dažnai pasireiškia po maudymosi sukūrinèse voniose. Jai būdingi lengvi, ị gripo panašūs simptomai bei trumpas inkubacinis periodas (6-48 val.)[19].

Sunki forma - pneumonija (Legioneliozè, legionierių liga) - inkubacinis periodas ilgesnis (2-14 d.), būdinga atipinè pneumonija $[2,10,19]$.

Legionelinė pneumonija. Tai atipinė pneumonija, kuri kliniškai gali priminti pneumokoko sukeltą ar kitas bakterines pneumonijas [11]. Ligos prodromas pasireiškia galvos skausmu, mialgijomis, astenija, anoreksija. Būdingas karščiavimas, bradikardija [20]. Karščiavimas gali nepasireikšti imunosupresiniams pacientams. Legioneliozei būdingi gastrointesticiniai ir neurologiniai simptomai [10,21]. Jeigu legionelès patenka ị virškinamajjị traktą, pasireiškia diarẻja, vėmimas, pykinimas, pilvo skausmas [20]. Neurologinè simptomatika paprastai pasireiškia galvos skausmu, tačiau sunkios ligos atveju, kartu su galvos skausmu, galimi traukuliai ar židininè neurologine simptomatika [10,22].

Simptomai pagal jų pasireiškimo dažnumą išvardyti 1 lentelèje[23].

Diagnostika. Vadovaujantis tik klinika, atskirti legioneliozę nuo kitos etiologijos pneumonijos sunku. Mikroskopuojant Gramo būdu dažytą tepinèli, paprastai sukèlèjo nematoma [7], todèl diagnozei nustatyti reikalingi specialūs

1 lentelè. Legioneliozès simptomai pagal jų pasireiškimo dažnumą.

\begin{tabular}{|l|c|}
\hline Simptomas & Dažnis, proc. \\
\hline Karščiavimas $>38,8^{\circ} \mathrm{C}$ & $67-100$ \\
\hline Kosulys & $41-92$ \\
\hline Šaltkrètis & $15-77$ \\
\hline Dispnėja & $36-56$ \\
\hline Karščiavimas $>40^{\circ} \mathrm{C}$ & $21-62$ \\
\hline Neurologinė simptomatika & $38-53$ \\
\hline Mialgijos, artralgijos & $20-43$ \\
\hline Diarèja & $19-47$ \\
\hline Krūtinės skausmas & $14-50$ \\
\hline Galvos skausmas & $17-43$ \\
\hline Pykinimas, vėmimas & $9-25$ \\
\hline
\end{tabular}


mikrobiologiniai ir imunologiniai tyrimai:

- Legionelès 1 serogupès antigeno nustatymas šlapime imunofermentiniu metodu. Šiuo tyrimu patvirtinama daugiau kaip 80 proc. legioneliozès atvejų. Šlapimo antigeno testo jautrumas yra 95 proc., specifiškumas - 95 proc., jautrumas pagerejja tiriant koncentruotą šlapimą [2]. Tyrimas būna teigiamas, nepaisant antimikrobinès terapijos. Po ligos antigenas šlapime gali persistuoti kelis mènesius [23]. Retais atvejais, klaidingai teigiamas atsakymas gali būti dèl reumatoidinio faktoriaus [11]. Pacientams, kuriems yra ligos simptomų, bet pradinis tyrimas neigiamas, rekomenduojama atlikti tyrimą su koncentruotu šlapimu arba kartoti antrą mèginį po keleto dienų $[2,11]$;

- Bronchoalveolinio lavažo, bronchų aspirato, skreplių pasèlis ị selektyvias terpes yra auksinis standartas diagnozuojant legioneliozę (jautrumas $80-90$ proc., specifiškumas - 100 proc.), tačiau dèl tyrimo trukmès (3-5 dienos) ir sudètingumo klinikineje praktikoje jis taikomas retai - juo patvirtinama mažiau nei 10 proc. legioneliozès atvejų [2]. Pasèlis būna teigiamas ir tuo atveju, jei ligonis jau yra gydomas antibiotikais [11]. Jis svarbus atliekant epidemiologinius tyrimus, norint identifikuoti užsikrètimo šaltini ar susieti kelis susirgimo atvejus, kadangi turint išaugintą bakterijų kultūrą iš kvėpavimo takų ėminių, galima atlikti legionelių genotipavimą, taikant molekulinio tipavimo metodus [23].

Legioneliozei būdingi nespecifiniai laboratoriniai tyrimai [11,24]:

- hiponatremija,

- hematurija,

- padidèję kepenų fermentai (ast, alt),

- hipofosfatemija,

- leukocitozè,

- trombocitopenija.

Gydymas. Gydoma gerai ị ląstelę penetruojančiais antibakteriniais preparatais. Pirmiausia rekomenduojami fluorchinolonai (Ciprinol), cefalosporinai (Ceftriaxon), makrolidai (azitromicinas arba klaritromicinas, kurie prasiskverbia i ląstelę [23]. Pradžioje antibakterinị gydymą reikia skirti parenteraliai, o geriamuosius vaistus - sumažèjus kūno temperatūrai [10]. Antibiotikų skyrimo trukmè priklauso nuo ligos formos bei sunkumo. Lengvos formos pneumonija gydoma azitromicinu 3-5 dienas [25]. Esant imunosupresinei būklei ar sergant sunkia pneumonijos forma, azitromiciną reikia skirti ilgiau - 14-21 dieną. Jeigu yra gretutinè žmogaus imunodeficito viruso (ŽIV) infekcija, gydoma savaitemis, iki visiško simptomų išnykimo. Gydymas azitromicinu galimas ir vaikams. Pontiako karštligė paprastai praeina savaime, antibiotikų neskiriama [26].

2013 m. JAV maisto ir vaistų administracija (angl. Food and Drug administration, sutr. FDA) papraše atnaujinti visų fluorochinolonų vaistų etiketes ir vaistų vadovus, kad geriau apibūdintų jų rimtą periferinès neuropatijos šalutinị poveikị, kuris gali būti nuolatinis ir ịspejo, kad azitromicinas gali sukelti nenormalų elektrinį širdies aktyvumą [27].

Antibiotiku profilaktika veiksminga, nustačius legioneliozès protrūkị didelès rizikos populiacijose [28].

Profilaktika. Legioneliozès prevencijai svarbi tinkama vandens sistemų, kuriose auga Legionella spp., priežiūra [23]. Reikia ne rečiau kaip 2 kartus per metus valyti ir dezinfekuoti oro kondicionavimo sistemų aušinimo bokštus ir vamzdžius [11]. Būtina valyti ir dezinfekuoti vandens šildytuvus, vandens filtrus, neleisti vandeniui užsistovèti, reguliariai valyti dušus, dušų galvutes ir vandens čiaupus, kad nesikauptų nuosėdos [10]. Dar 2003 m. JAV sveikatos priežiūros infekcijų kontrolès praktikos patariamojo komiteto gairèse, skirtose užkirsti kelią su sveikatos priežiūra susijusiai pneumonijai, rekomenduota strategija, orientuota ị tinkamą vandens sistemos priežiūrą, visuotinį ligonių, sergančių hospitaline pneumonija, tyrimą ir situacijų, kuriose užsikrečiama, tyrimą [29]. Vandens temperatūra turi būti palaikoma $50-60{ }^{\circ} \mathrm{C}$, šalto vandens temperatūra neturi siekti $20{ }^{\circ} \mathrm{C}[30]$. Turi būti vykdomi vandens mikrobiologiniai tyrimai ligoninèse, kuriose atliekamos organų ir kaulų čiulpu persodinimo operacijos [29]. Po vandens šildytuvų remonto ir prieš šildymo sezoną reikia dezinfekuoti karšto vandens sistemas [29]. Vandens dezinfekcijai turi būti taikomi jonizacijos, vandens kaitinimo $\left(60-77^{\circ} \mathrm{C}\right)$ visoje sistemoje $25 \mathrm{~min}$. ir paskirstymo sistemų plovimo, sudarant aukštą vandens spaudimą, metodai $[29,30]$.

\section{Išvados}

1. Legionelinė pneumonija turètų visad būti apsvarstyta, esant netipinès pneumonijos pasireiškimui.

2. Specifinio legionelès antigeno šlapime nustatymas turètų būti atliktas visiems ligoniams, kuriems diagnozuota sunki visuomeneje igyta pneumonija, bei tiems, kuriems epidemiologiškai ịtariama legioneliozè.

3. Atskiri legioneliozès atvejai turètų būti laiku ir išsamiai ištirti, nes jie gali sukelti didesni galimą protrūkį.

4. Stabdant legionelès plitimą bei protrūkius, svarbu tinkama vandens sistemų priežiūra. Liga plinta per vandens sistemas, kurias naudoja daug žmonių, todèl būtina ją identifikuoti ir apie tai pranešti atitinkamoms savo šalies institucijoms.

\section{Literatūra}

1. Centers for Disease Control and Prevention (CDC). Legionnaires Disease History, Burden, and Trends 2021. https://www.cdc. gov/legionella/about/history.html

2. Legioneliozè. ULAC. http://www.ulac.lt/ligos/L/legionelioze 
3. Falconi TMA, Cruz MS, Naumova EN. The Shift in Seasonality of Legionellosis in the U.S. Epidemiol Infect 2018;146(14):1824-33.

https://doi.org/10.1017/S0950268818002182

4. Centers for Disease Control and Prevention (CDC). Legionellosis --- United States, 2000-2009. MMWR Morb Mortal Wkly Rep 2011;60(32):1083-6.

5. Fields BS, Benson RF, Besser RE. Legionella and Legionnaires' disease: 25 years of investigation. Clin Microbiol Rev 2002;15(3):506-26.

https://doi.org/10.1128/CMR.15.3.506-526.2002

6. Farnham A, Alleyne L, Cimini D, Balter S. Legionnaires' disease incidence and risk factors, New York, New York, USA, 20022011. Emerg Infect Dis 2014;20(11):1795-802.

https://doi.org/10.3201/eid2011.131872

7. Yates TA, Bruin JP, Harrison TG, Mannes T. Molecular diagnostics and the public health management of legionellosis. BMJ Case Rep 2013;2013:bcr2013008713. https://doi.org/10.1136/bcr-2013-008713

8. Montagna MT, De Giglio O, Napoli C, Diella G, Rutigliano S, Agodi A, et al. Control and prevention measures for legionellosis in hospitals: A cross-sectional survey in Italy. Environ Res 2018;166:55-60. https://doi.org/10.1016/j.envres.2018.05.030

9. Benson RF, Fields BS. Classification of the genus Legionella. Semin Respir Infect 1998;13(2):90-9.

10. Cunha BA, Burillo A, Bouza E. Legionnaires' disease. Lancet Lond Engl 2016;387(10016):376-85. https://doi.org/10.1016/S0140-6736(15)60078-2

11. Marrie TJ, Garay JR, Weir E. Legionellosis: Why should I test and report? CMAJ Can Med Assoc J 2010;182(14):1538-42. https://doi.org/10.1503/cmaj.082030

12. Burillo A, Pedro-Botet ML, Bouza E. Microbiology and Epidemiology of Legionnaire's Disease. Infect Dis Clin North Am 2017;31(1):7-27.

https://doi.org/10.1016/j.idc.2016.10.002

13. Dondero TJ, Rendtorff RC, Mallison GF, Weeks RM, Levy JS, Wong EW, et al. An outbreak of Legionnaires' disease associated with a contaminated air-conditioning cooling tower. $\mathrm{N}$ Engl J Med 1980;302(7):365-70.

https://doi.org/10.1056/NEJM198002143020703

14. Cordes LG, Fraser DW, Skaliy P, Perlino CA, Elsea WR, Mallison GF, et al. Legionnaires' disease outbreak at an Atlanta, Georgia, Country Club: evidence for spread from an evaporative condenser. Am J Epidemiol 1980;111(4):425-31. https://doi.org/10.1093/oxfordjournals.aje.a112917

15. Delia $\mathrm{S}$, Laganà $\mathrm{P}$, Minutoli E. Occurrence of Legionella in beach shower facilities. J Prev Med Hyg 2007;48(4):114-7.

16. Lam MC, Ang LW, Tan AL, James L, Goh KT. Epidemiology and control of legionellosis, singapore. Emerg Infect Dis 2011;17(7):1209-15. https://doi.org/10.3201/eid1707.101509

17. Common Risk Factors - Legionella.org. https://legionella. org/about-the-disease/what-is-legionnaires-disease/commonrisk-factors/

18. Lanternier F, Tubach F, Ravaud P, Salmon D, Dellamonica P, Bretagne $\mathrm{S}$, et al. Incidence and Risk Factors of Legionella pneumophila Pneumonia During Anti-Tumor Necrosis Factor Therapy: A Prospective French Study. Chest 2013;144(3):990-8. https://doi.org/10.1378/chest.12-2820

19. Hamilton KA, Prussin AJ, Ahmed W, Haas CN. Outbreaks of Legionnaires' Disease and Pontiac Fever 2006-2017. Curr Environ Health Rep 2018;5(2):263-71.

https://doi.org/10.1007/s40572-018-0201-4

20. Cunha BA. Clinical features of legionnaires' disease. Semin Respir Infect 1998;13(2):116-27.

21. Parr A, Whitney EA, Berkelman RL. Legionellosis on the Rise: A Review of Guidelines for Prevention in the United States. J Public Health Manag Pract JPHMP 2015;21(5):E17-26. https://doi.org/10.1097/PHH.0000000000000123

22. Mulazimoglu L, Yu VL. Can Legionnaires disease be diagnosed by clinical criteria? A critical review. Chest 2001;120(4):1049-53. https://doi.org/10.1378/chest.120.4.1049

23. Cunha BA, Burillo A, Bouza E. Legionnaires' disease. The Lancet 2016;387(10016):376-85. https://doi.org/10.1016/S0140-6736(15)60078-2

24. Meyer RD. Legionella infections: a review of five years of research. Rev Infect Dis 1983;5(2):258-78.

https://doi.org/10.1093/clinids/5.2.258

25. Sánchez F, Mensa J, Martínez JA, Badia R, Albarracín M, Losa JE, et al. [Treatment of pneumonia caused by Legionella with azithromycin]. Rev Espanola Quimioter Publicacion Of Soc Espanola Quimioter 1998;11(2):147-51.

26. Pedro-Botet ML, Yu VL. Treatment strategies for Legionella infection. Expert Opin Pharmacother 2009;10(7):1109-21. https://doi.org/10.1517/14656560902900820

27. Research C for DE and. FDA Drug Safety Communication: Azithromycin (Zithromax or Zmax) and the risk of potentially fatal heart rhythms. FDA 2019. https://www.fda.gov/drugs/ drug-safety-and-availability/fda-drug-safety-communicationazithromycin-zithromax-or-zmax-and-risk-potentially-fatalheart

28. Gudiol C, Verdaguer R, Angeles Domínguez M, FernándezSevilla A, Carratalà J. Outbreak of Legionnaires' disease in immunosuppressed patients at a cancer centre: usefulness of universal urine antigen testing and early levofloxacin therapy. Clin Microbiol Infect 2007;13(11):1125-8.

https://doi.org/10.1111/j.1469-0691.2007.01805.x

29. Sehulster L, Chinn RYW, CDC, HICPAC. Guidelines for environmental infection control in health-care facilities. Recommendations of CDC and the Healthcare Infection Control Practices Advisory Committee (HICPAC). MMWR Recomm 
Rep 2003;52(RR-10):1-42.

30. Stout JE, Muder RR, Mietzner S, Wagener MM, Perri MB, DeRoos K, et al. Role of environmental surveillance in determining the risk of hospital-acquired legionellosis: a national surveillance study with clinical correlations. Infect Control Hosp Epidemiol 2007;28(7):818-24.

https://doi.org/10.1086/518754

\section{LEGIONNAIRE'S DISEASE. WHY IS IT IMPORTANT TO IDENTIFY AND REPORT \\ Š. Masys, E. Naujalis, D. Kaušaitè}

Keywords: legionellosis, Legionnaires' disease, Legionella pneumophila, pneumonia.

Summary

Legionnaires' disease is a form of atypical pneumonia, caused by any species of Legionella bacteria, quite often Legionella pneumophila. Legionnaires' disease can be acquired by the inhalation of contaminated water aerosols or the aspiration of contaminated potable water. LD is notifiable in all 31 European Union/ European Economic Area (EU/EEA) countries, where ca $70 \%$ of all reported cases are community-acquired, $20 \%$ travel-associated, and $10 \%$ healthcare-related. The incubation period of legionnaires' disease is between 2 and 10 days

Patients with legionnaires' disease are more likely than those whose community-acquired pneumonia was caused by another agent to have myalgia, headache, and diarrhea; they also have a higher mean oral temperature at the time of presentation. There are no individual clinical features that allow physicians to make a diagnosis of legionnaires' disease; however, all patients with severe pneumonia should be tested for legionnaires' disease. The clinical diagnosis of legionnaires' disease can be confirmed by the isolation of the organism from sputum, bronchoalveolar lavage fluid, pleural fluid, or pulmonary tissue. Detection of the antigen in the urine is a useful test for L. pneumophila serogroup 1. Guidelines for the empirical treatment of these illnesses call for the use of either fluoroquinolones or macrolides. Patients and physicians may feel that it is therefore not necessary to confirm the diagnosis of legionellosis to treat it. However, from the perspective of public health, the diagnosis is confirmed and reported so that the possibility of an outbreak and the source of exposure can be investigated. The aim of this article is to review the etiology, epidemiology, diagnostics, treatment, prevention and the importance of report about Legionnaires' disease.

Correspondence to: dominyka.kausaite@gmail.com

Gauta 2021-05-19 